Meta

Journal des traducteurs

Translators' Journal

\title{
Translation-Strategies Use: A Classroom-Based Examination of Baker's Taxonomy
}

\section{Pilar Aguado-Giménez et Pascual-Francisco Pérez-Paredes}

Volume 50, numéro 1, mars 2005

Enseignement de la traduction dans le monde

Teaching Translation Throughout the World

URI : https://id.erudit.org/iderudit/010675ar

DOI : https://doi.org/10.7202/010675ar

Aller au sommaire du numéro

Éditeur(s)

Les Presses de l'Université de Montréal

ISSN

0026-0452 (imprimé)

1492-1421 (numérique)

Découvrir la revue

Citer cet article

Aguado-Giménez, P. \& Pérez-Paredes, P.-F. (2005). Translation-Strategies Use: A Classroom-Based Examination of Baker's Taxonomy. Meta, 50(1), 294-311.

https://doi.org/10.7202/010675ar
Résumé de l'article

L'enseignement des stratégies de traduction fait à présent partie des cours de traduction offerts à l'université. Les méthodes comme celles que Mona Baker a développées sont utilisées pour différentes raisons. Premièrement, elles permettent de résoudre les problèmes d'équivalence linguistique ;

deuxièmement, elles impliquent la compréhension du concept de traduction en tant que système ; troisièmement, l'étude des stratégies de traduction permet aux élèves d'évaluer les questions théoriques et leurs contextes.

Dans cette étude, les auteurs explorent les stratégies utilisées dans des traductions faites par des étudiants espagnols au premier cycle universitaire de l'anglais à l'espagnol. Cette exploration passe en revue et approfondit la taxonomie de Mona Baker. Une des conclusions c'est que l'enseignement des stratégies de traduction conduit à l'élaboration de traductions de plus grande qualité en général, correction et précision. En même temps, ce projet présente une évaluation concernant le choix des stratégies.
Ce document est protégé par la loi sur le droit d'auteur. L'utilisation des services d’Érudit (y compris la reproduction) est assujettie à sa politique d'utilisation que vous pouvez consulter en ligne.

https://apropos.erudit.org/fr/usagers/politique-dutilisation/ 


\title{
Translation-Strategies Use: A Classroom-Based Examination of Baker's Taxonomy
}

\author{
PILAR AGUADO-GIMÉNEZ and \\ PASCUAL-FRANCISCO PÉREZ-PAREDES \\ University of Murcia, Murcia, Spain \\ paguado@um.es
}

\begin{abstract}
RÉSUMÉ
L'enseignement des stratégies de traduction fait à présent partie des cours de traduction offerts à l'université. Les méthodes comme celles que Mona Baker a développées sont utilisées pour différentes raisons. Premièrement, elles permettent de résoudre les problèmes d'équivalence linguistique; deuxièmement, elles impliquent la compréhension du concept de traduction en tant que système; troisièmement, l'étude des stratégies de traduction permet aux élèves d'évaluer les questions théoriques et leurs contextes.

Dans cette étude, les auteurs explorent les stratégies utilisées dans des traductions faites par des étudiants espagnols au premier cycle universitaire de l'anglais à l'espagnol. Cette exploration passe en revue et approfondit la taxonomie de Mona Baker. Une des conclusions c'est que l'enseignement des stratégies de traduction conduit à l'élaboration de traductions de plus grande qualité en général, correction et précision. En même temps, ce projet présente une évaluation concernant le choix des stratégies.
\end{abstract}

\begin{abstract}
Teaching translation strategies has become a relevant part of university translation courses. Strategies, such as those outlined by Mona Baker, are useful in different ways. First, they help solve equivalence problems; second, they favour translation-as-a-process awareness and, third, they present students with opportunities to discuss and reflect on contextualized theoretical issues. In this study, the authors set out to explore, in terms of strategy use, English into Spanish translations produced by undergraduate university students $(n=160)$. As a result, Mona Baker's taxonomy is reviewed and enlarged. Some of the conclusions point out to the fact that translation strategies teaching favours both the quality and the accuracy of the translations. Similarly, a discussion on strategy choice is presented.
\end{abstract}

\section{MOTS-CLÉS/KEYWORDS}

Baker's taxonomy, classroom-based examination, translation strategies, translation theory

\section{Introduction}

Finding equivalences to convey the same meaning of a source language text in a target language is not always an easy task. The difficulties associated with the process of translation have been widely commented on by scholars and professional translators, but they become highly remarkable when we deal with language students learning to translate into their native language. To overcome the difficulties arising from translating texts, students should be introduced to the theory of translation, and should be trained in the various strategies to solve translating problems and the lack of translation equivalences among languages. 
To see how students solve translation problems, an experiment was carried out with students of English Studies. The group of informants was formed by 160 students in their third year. They were attending a course in General Translation, and they were supposed to have an upper-intermediate/advanced level of English. Before dealing with the practice of translation, these students were introduced to some basic concepts on translation theory, and different studies on equivalence. They were instructed in Mona Baker's categories of equivalence (1992), and the different strategies employed to solve non-equivalence situations, paying attention to the word level, the aboveword level, and the question of lexical meaning and its types (in her work In Other Words (1992), Mona Baker offers a clear and systematic set of strategies related to the different levels of study of language and discourse, understandable by the learners and easy to study and apply).

\subsection{Students' training in translation theory}

Before dealing in detail with the translation strategies proposed by Baker, the students were introduced to some basic concepts in the theory of translation. They were instructed in the different factors that are involved in the process of translating. Such factors, which will be later related to specific strategies, are, as Newmark (1988) states:

FIGURE 1

Factors affecting translation

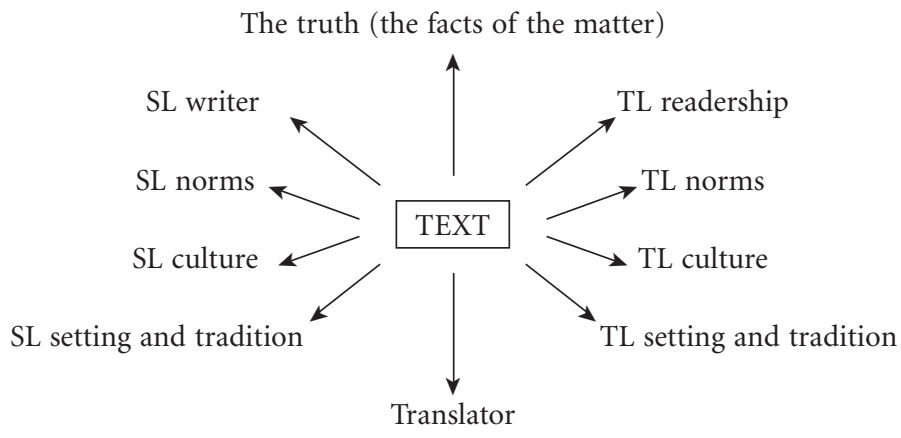

Students should be aware that their work as translators is developed in four levels (Newmark 1981, 1988): translation as a science, which entails the knowledge and verification of the facts and the language that describes them; translation as a skill, which calls for appropriate language and acceptable usage; translation as an art, which distinguishes good from undistinguished writing and is the creative, the intuitive, sometimes the inspired, level of the translation; and finally, translation as a matter of taste, where argument ceases, preferences are expressed, and the variety of meritorious translations is the reflection of individual differences. Students were also introduced to the works of Susan Basnett (1991) and Snell-Hornby (1995). Students, working as translators, are continually faced with choices. In making them, they are intuitively or consciously following a theory of translation. What translation theory actually does is to identify and define a translation problem; to indicate all the factors that have to be taken into account in solving the problem, to list all the possible 
translation procedures, and finally, to recommend the most suitable translation procedure, plus the appropriate translation. This is why translation is a decision-making process and a problem-solving task:

- Decision-making, because of the choices the translator faces. As Hatim \& Mason (1990:12) say, translation is a matter of choice, but choice is always motivated: omissions, additions and alterations may indeed be justified but only in relation to intended meaning."

- Problem-solving, as the translator is always "trying to solve a thousand small problems in the context of a large one" (Newmark, 1988:8).

When involved in the process of translation, students have to face many different problems, at different levels. To help them overcome these situations, they were also introduced to Kussmaul's (1995) list of instructions to solve translation problems.

Once the students have a basic knowledge of what translation theory is, they were instructed in the different steps followed to translate a text: reading the source language text, finding an equivalent, and judging the target text. Regarding the first step, the students have to realize the importance of the skill of reading, to get the gist of the text they are going to translate. The complete comprehension and analysis of the source text are the only ways to a good translation.

The second step proposed is closely linked with the use of strategies, as they are going to become the most important tools for the transmission of the meaning and form of the original text into the target language. Here the concept of equivalence is of great significance, and several authors have dealt with it. Catford (1965:20) writes "translation may be defined as follows: The replacement of textual material in one language (SL) by equivalent textual material in another language (TL)," and maintains that "the central problem of translation practice is finding TL translation equivalents" (1965:12), and Nida (1964) distinguished between formal and dynamic equivalence. Formal equivalence is the closest possible match of form and content between source text and target text, while dynamic equivalence is the equivalence of effect on the target reader. The students have to bear in mind that finding an equivalent is a difficult task and involves careful consideration of the many various solutions the target language offers, and the use of strategies where no exact translation appears.

Finally, students have to judge their translation in terms of what their final text is trying to achieve. In this respect, several scholars have proposed some considerations to be taken into account to get a quality job, such as Nida (1964), Tytler (1907) and Newmark (1988).

Once students have received this information about the process of translation and the many factors implied, they were instructed in the different translation strategies depending on the level they occur: at word level, above the word level, grammatical, textual, and pragmatic equivalences (Baker, 1992).

After a semester period of theoretical instruction and practice on translation, the 160 informants were tested to see if they had inferred the most important translation concepts, and if they had acquired some techniques and/or strategies to translate and produce better target texts. 8.7 in ten students were Spanish native speakers whereas 1.6 in ten were English natives. The rest were from other European countries. Further information is provided later on in the Sample section. All of them were given two texts to practise direct and indirect translation, English-Spanish and Spanish-English or vice-versa depending on their L1. 


\section{Method}

\subsection{Instruments: translation units}

In this study we are going to pay attention to English into Spanish translation and the strategies shown in dealing with specific translation problems. We were mainly concerned with the translation of nominal groups which showed some difficulty for Spanish learners of English, in terms of lexis and grammatical structure, paying special attention to the nucleus of these groups. All Noun Phrases (NPs) were selected for three reasons: they represent the most relevant constituency relationships found in the English Noun Phrase, they present a wide range of potential problems when translated into Spanish and, finally, their position in the ST, distributed all throughout, made them critical for the full understanding of the sense of the text. Besides, when selecting the lexical items to be translated into the TL we decided to keep the type of grammatical unit under scrutiny constant. That way we hope more coherent conclusions can be contrasted and reached. A more detailed account of the NPs studied is provided below. The text translated, which was a synopsis from Shakespeare in Love video movie, was (in bold characters, the nominal groups studied):

Triumphant winner of 7 Academy Awards - including Best Picture - this witty, sexy smash features Oscar-winning Best Actress Gwyneth Paltrow (Sliding Doors, A Perfect Murder) and an amazing cast that includes Academy Award winners Judy Dench (Best Supporting Actress), Geoffrey Rush (Best Actor - Shine) and Ben Affleck (Armageddon; Best Original Screenplay - Good Will Hunting)! When Will Shakespeare (Joseph Fiennes Elizabeth) needs passionate inspiration to break a bad case of writer's block, a secret romance with the beautiful Lady Viola (Paltrow) starts the words flowing like never before! There are just two things he'll have to learn about this new love: not only is she promised to marry someone else, she's successfully impersonating a man in order to play the lead in Will's latest production! A truly can't-miss motion picture event with outstanding critical acclaim to match its impressive collection of major awards - everyone will love this funny behind-the-scenes look at the writing of the greatest love story ever told!

As a reference, exact translations were supposed to be the ones most approximated to the following:

TABLE 1

Noun Phrases analyzed in this study and Spanish equivalences

\begin{tabular}{|l|l|l|}
\hline This witty, sexy smash & NP 1 & $\begin{array}{l}\text { Este gran éxito lleno de ingenio y } \\
\text { sensualidad }\end{array}$ \\
\hline An amazing cast & NP 2 & Un prestigioso elenco/ reparto de actores \\
\hline Best supporting actress & NP 3 & Mejor actriz secundaria/ de reparto \\
\hline Writer's block & NP 4 & Falta de inspiración \\
\hline A truly can't-miss motion picture event & NP 5 & $\begin{array}{l}\text { Un acontecimiento cinematográfico } \\
\text { verdaderamente inolvidable }\end{array}$ \\
\hline Outstanding critical acclaim & NP 6 & Destacada aclamación de la crítica \\
\hline This funny behind-the-scenes look & NP 7 & $\begin{array}{l}\text { Esta agradable mirada detrás del telón/ } \\
\text { entre bambalinas }\end{array}$ \\
\hline
\end{tabular}




\subsection{Instruments: Baker's taxonomy}

From the instruction received during the course, the students were expected to use Baker's strategies at word level in their translations, which are based on the different types of lexical meaning we find in words and utterances (propositional, expressive, presupposed and evoked meanings, Baker, 1992, pp. 13-17). After dealing with the difficulties implied in the lack of equivalence at word level, Baker proposes the following classification of strategies used by professional translators (1992, pp. 26-42):

TABLE 2

Baker's (1992) taxonomy of translation strategies

\begin{tabular}{|c|l|l|}
\hline 1 & STRATEGY & $\begin{array}{l}\text { COMMENTS } \\
\text { (superordinate) }\end{array}$ \\
\hline 2 & $\begin{array}{l}\text { Translation by a more neutral/less } \\
\text { expressive word }\end{array}$ & $\begin{array}{l}\text { Related to propositional meaning. It works in } \\
\text { most languages (p. 26) }\end{array}$ \\
\hline 3 & Translation by cultural substitution & $\begin{array}{l}\text { This strategy involves replacing a culture-specific } \\
\text { item with a target language item which does not } \\
\text { have the same propositional meaning but is likely } \\
\text { to have a similar impact on the target reader (p. } 31 \text { ) }\end{array}$ \\
\hline 4 & Translation using a loan word & $\begin{array}{l}\text { Related with culture-specific items, modern loan } \\
\text { word plus explanation concepts and buzz words } \\
\text { (p. 34) }\end{array}$ \\
\hline 5 & $\begin{array}{l}\text { Translation by paraphrase using } \\
\text { a related word }\end{array}$ & $\begin{array}{l}\text { This is used when the concept expressed by the } \\
\text { source item is lexicalized in the target language } \\
\text { but in a different form, and when the frequency } \\
\text { of use in the source language is higher than in } \\
\text { the target language (p. 37) }\end{array}$ \\
\hline 7 & $\begin{array}{l}\text { Translation by paraphrase using } \\
\text { unrelated words }\end{array}$ & $\begin{array}{l}\text { This is used when the concept in the source } \\
\text { language is not lexicalized in the target language } \\
\text { (p. 38) }\end{array}$ \\
\hline
\end{tabular}

\subsection{Instruments: Students' performance strategies}

However, we found that the set of strategies that students used varied slightly from the one proposed by Baker, which was the one taught in class. A new classification emerged from the study carried out with the students' translations (comments are made on new strategies). New emerging strategies appear shaded in Table 3. Note that the examples given may result either in success or failure, depending on their adequacy and lexical TL proximity to the exact, equivalent translation. 
TABLE 3

Translation strategies used by our sample of students

\begin{tabular}{|c|c|c|c|}
\hline & STRATEGY & COMMENTS & $\begin{array}{l}\text { EXAMPLES } \\
\text { Reference to NP in brackets }\end{array}$ \\
\hline 1 & $\begin{array}{l}\text { Translation by a more } \\
\text { general word (superordinate) }\end{array}$ & See table 2 & $\begin{array}{l}\text { Esta ingeniosa y sexy } \\
\text { película (NP 1) }\end{array}$ \\
\hline 2 & Translation by a more neutral/ & See table 2 & $\begin{array}{l}\text { Esta ingeniosa } \\
\text { producción (NP 2) }\end{array}$ \\
\hline 3 & $\begin{array}{l}\text { Translation by cultural } \\
\text { substitution }\end{array}$ & See table 2 & No examples found \\
\hline 4 & $\begin{array}{l}\text { Translation using a loan word } \\
\text { or loan word plus explanation }\end{array}$ & See table 2 & Un magnífico casting (NP2) \\
\hline 5 & Translation using a related word & $\begin{array}{l}\text { Use of the same word, } \\
\text { even if it is inflected or } \\
\text { derived. No change of } \\
\text { grammatical category } \\
\text { is detected. }\end{array}$ & Bloqueo del escritor (NP 4) \\
\hline 6 & $\begin{array}{l}\text { Translation by paraphrase } \\
\text { using unrelated words }\end{array}$ & $\begin{array}{l}\text { Use of paraphrase strategy } \\
\text { using unrelated words. }\end{array}$ & $\begin{array}{l}\text { La falta de originalidad por } \\
\text { la que atraviesa (NP 4) }\end{array}$ \\
\hline 7 & Translation by omission & See table 2 & Hay actores (NP 2) \\
\hline 8 & Translation by a new category & $\begin{array}{l}\text { Use of a new word with } \\
\text { no paraphrase, which } \\
\text { turns into a new } \\
\text { grammatical category. }\end{array}$ & $\begin{array}{l}\text { Que la crítica especializada } \\
\text { aclama (NP 6) }\end{array}$ \\
\hline 9 & $\begin{array}{l}\text { Translation by an unusual } \\
\text { collocation in the target } \\
\text { language }\end{array}$ & $\begin{array}{l}\text { Use of an unusual } \\
\text { collocation in the target } \\
\text { language. }\end{array}$ & $\begin{array}{l}\text { Un maravilloso repertorio } \\
\text { de actores (NP 2) }\end{array}$ \\
\hline
\end{tabular}

Underlying our research is the fact that all seven English Noun Phrases under scrutiny do actually present a lexicalized equivalent in Spanish (see Table 1). This makes an important difference with Baker's taxonomy as students were expected to either return these equivalences or fall back on translation strategies to compensate their lack of familiarity with those lexical items. As is apparent, some new strategies were identified based on evidence provided by the students' translations into Spanish. The following strategies diverge from Baker's original classification:

- Translation using a related word (\#5). This strategy is not exactly a paraphrase, as first proposed by Baker (see Table 2, \# 5). There actually exists an exact lexicalized equivalent in terms of grammatical category in Spanish which is not used by the students. Instead, the ST lexical item is translated into the TT using the same word, even if it is inflected or derived. This situation generates as both languages here share similar lexical origins (Latin / French word stocks in English and Spanish). For example, in NP 4, (see Table 1) strategy \# 5 is used successfully in "bloqueo del escritor/ autor" and results in failure in "bloqueo mental para escribir" as it presents potential Spanish readers with an unacceptable pragmatic translation of the NP. Yet, the strategy is there. 
- Translation by paraphrase using unrelated words (\#6). In this strategy, students paraphrase the ST NPs using unrelated words. We understand that this strategy does diverge from Baker's \#6 in the fact that the SL concepts are actually lexicalized in the TL (see Table 1). In this strategy, sometimes an amount of definition/explanation is provided in order to characterize the term translated. For example, in NP 9, a student proposed the following: "esta divertida historia que transcurre entre bastidores," explaining clearly the idea presented in the SL phrase.

- Translation by a new category (\#8). This strategy, again, differs from Baker's \#5. While in Baker's the concept expressed in the SL in lot lexicalized in the TL in the same form but in a different one, in this reformulated strategy framework the term does exist. On this occasion, the student uses a word derived from the equivalent lexical item, but changing it into a new grammatical category. For example, NP 6 has been widely translated using this strategy. From the correct translation proposed ("destacada aclamación de la crítica") we find good attempts at using this strategy, such as "una crítica excepcional," where "crítica" is the noun derived from the correspondent equivalent, or "que la crítica especializada aclama," where "crítica" and "aclama" are the noun and the verb derived from "crítico" and "'aclamación" respectively.

- Translation by an unusual collocation (\#9). Using this strategy, the students offer attempts of translations which result in unusual collocations, although they cannot be considered either right or wrong. For example, NP 6 has been translated as "una alta aclamación de la crítica," where "alta" and "aclamación" do not collocate in Spanish. However, this translation cannot be considered as totally wrong, for "alta" shares some lexical characteristics with "destacada/ sobresaliente": positive, high degree, applied to things, etc.

The translation by illustration is omitted as the two languages are not so extremely different so as not to find a linguistic expression or a source language piece of text.

In this study data was collected from one hundred and sixty $(n=160)$ students of the Degree in English Philology offered by the University of Murcia, Spain. The population consisted of 33 male students (20.6\%) and 127 female learners (79.4\%). One hundred and forty were Spanish citizens with Spanish as mother tongue $(87.5 \%)$, seventeen had English as $\mathrm{L}_{1}(10.6 \%)$ and three other nationalities accounted for the remaining 1.8\%: one French, one Finnish and one Dutch.

\subsection{Instruments: measure of students' translation competence}

For every individual, two sets of scores were obtained. The first was aimed at assessing the extent to which theoretical translation issues had been understood and grasped. To that effect, we developed a multiple choice test which offered a potential score range of 0 to 50 . The test consisted of $50 \mathrm{MC}$ questions about the topics introduced in the subject syllabus, which covered the subsequent areas:

1. Basic questions and concepts in translation. Translation as a problem-solving task. Problems involved in translating. Understanding the original text. Finding an equivalent. Judging the target text.

2. Equivalence at word level. The word in different languages. Lexical meaning. Problems of non-equivalence. Strategies for the translation of words.

3. Equivalence above word level. Collocation. Collocational range and collocational markedness. Collocation and register. Collocational meaning. Collocation problems in 
translation. Idioms and fixed expressions. The translation of idioms: difficulties. The translation of idioms: strategies.

4. Grammatical equivalence. Grammatical vs. Lexical categories. Grammatical categories across languages. Word order. Introducing text.

5. Textual equivalence. Thematic and information structures. Cohesive devices: reference, substitution, ellipsis, conjunction and lexical cohesion.

6. Pragmatic equivalence. Coherence. Coherence and processes of interpretation.: implicature. Coherence, implicature and translation strategies.

Students had 1 hour and a half to deal with the theoretical part of the test, and 2 hours for the translation part. No tool was allowed in the practical part, such as dictionaries, glossaries or other lists of vocabulary, as well as grammars.

In our study, the minimum score was 9 and the maximum was 44 , the mean $\bar{x}=$ was 28.0059 and the median 28.5500. The contents of that test included translation strategies as a central component. The students were further classified according to five different ranges of scores: (1/ poor performance) scores up to 10; (2/ weak performance) scores up to 20; (3/ acceptable performance) scores up to 30; (4/ very good performance) scores up to 40 and (5/ excellent performance) scores up to 50 . This is our students' profile:

TABLE 4

Students' profile/ theory test

\begin{tabular}{|c|c|}
\hline Range 1 & $1.3 \%$ \\
\hline Range 2 & $12.4 \%$ \\
\hline Range 3 & $49.7 \%$ \\
\hline Range 4 & $32.7 \%$ \\
\hline Range 5 & $3.9 \%$ \\
\hline
\end{tabular}

The results show that $86 \%$ of the sample used in this study have a good-to-verygood command of basic theoretical issues underlying the translation process. That meant that the students had acquired at least a basic set of information on translation theory.

Next, students were presented with a text in English which had to be translated into Spanish. The type of text had previously been studied in detail during the semester. Seven Noun Phrases were selected and became subject to analysis by researchers. These NPs display all six types of premodifying items identified by Greembaum and Quirk (1990), that is, adjective phrases, participles, s-genetive, nouns, clauses and adverb phrases. NP 1 consists of a determiner plus multiple adjective premodification plus headword, NP 2 duplicates the structure, but adjective premodification is lighter, NP 3 leaves determinatives out, and NP 4 has a saxon genitive premodifying the headword. In NP 5 we find a certainly complex string of elements before the headword: determiner plus adverb phrase plus clause plus noun phrase plus headword. In NP 6 we again have adjective phrase modification, whereas in NP 7, a somewhat unusual string appears: determiner plus adjective phrase plus prepositional phrase plus headword. 


\section{Results}

The students' translations were extracted by the researchers and a first run of analysis was performed in order to classify students' translations in three groups. We should observe that the use of strategies on the part of the students can lead either to successful or failed approaches to the right translation. In our study, only the former were considered. Group 1 consisted of translations where an exact equivalent in the TL had been used. Group 2 consisted of acceptable translations in which a strategy had been detected. Finally, group 3 consisted of totally unacceptable translations. The following is the results for each NP translations into Spanish:

TABLE 5

NP 1 THIS WITTY, SEXY SMASH

\begin{tabular}{|c|c|c|}
\hline & Frequencies & $\%$ \\
\hline Group 1 & 2 & 1.3 \\
\hline Group 2 & 43 & 26.9 \\
\hline Group 3 & 115 & 71.9 \\
\hline
\end{tabular}

TABLE 6

NP 2 AN AMAZING CAST

\begin{tabular}{|c|c|c|}
\hline & Frequencies & $\%$ \\
\hline Group 1 & 110 & 68.8 \\
\hline Group 2 & 33 & 20.6 \\
\hline Group 3 & 17 & 10.6 \\
\hline
\end{tabular}

TABLE 7

NP 3 BEST SUPPORTING ACTRESS

\begin{tabular}{|c|c|c|}
\hline & Frequencies & $\%$ \\
\hline Group 1 & 138 & 86.3 \\
\hline Group 2 & 7 & 4.4 \\
\hline Group 3 & 15 & 9.4 \\
\hline
\end{tabular}

TABLE 8

NP 4 WRITER'S BLOCK

\begin{tabular}{|c|c|c|}
\hline & Frequencies & $\%$ \\
\hline Group 1 & 33 & 20.6 \\
\hline Group 2 & 66 & 41.3 \\
\hline Group 3 & 61 & 38.1 \\
\hline
\end{tabular}

TABLE 9

NP 5 A TRULY CAN'T-MISS MOTION PICTURE EVENT

\begin{tabular}{|c|c|c|}
\hline & Frequencies & $\%$ \\
\hline Group 1 & 24 & 15 \\
\hline Group 2 & 87 & 54.4 \\
\hline Group 3 & 49 & 30.6 \\
\hline
\end{tabular}


TABLE 10

NP 6 OUTSTANDING CRITICAL ACCLAIM

\begin{tabular}{|c|c|c|}
\hline & Frequencies & $\%$ \\
\hline Group 1 & 9 & 5.6 \\
\hline Group 2 & 89 & 55.6 \\
\hline Group 3 & 62 & 38.8 \\
\hline
\end{tabular}

TABLE 11

NP 7 THIS FUNNY BEHIND-THE-SCENES LOOK

\begin{tabular}{|c|c|c|}
\hline & Frequencies & $\%$ \\
\hline Group 1 & 28 & 17.5 \\
\hline Group 2 & 34 & 21.3 \\
\hline Group 3 & 98 & 61.3 \\
\hline
\end{tabular}

On average, group 1 translations account for $30.7 \%$ of the total, group 2 translations for $32.07 \%$ and group 3 translations account for $37.24 \%$. Although very similar, the three means tell us about the fact that strategies are a powerful tool for learners to approach acceptable translations. It is important to note, however, that group distribution appears to be heavily NP-bound. See Figure 2 for details on how the translation of every single NP behaves and distributes in terms of the translation categorization (Groups 1, 2 and 3 represented on Y-axis) stated above. Three groups of frequency of translation categories are presented according to prevalence in each NP (Dominant, Middle and Least Prominent).

FIGURE 2

Translation categorization distribution across NPs. On Y-axis $1=$ translations where an exact equivalent in the TL had been used, 2 = acceptable translations in which a strategy had been detected, and 3 = totally unacceptable translations.

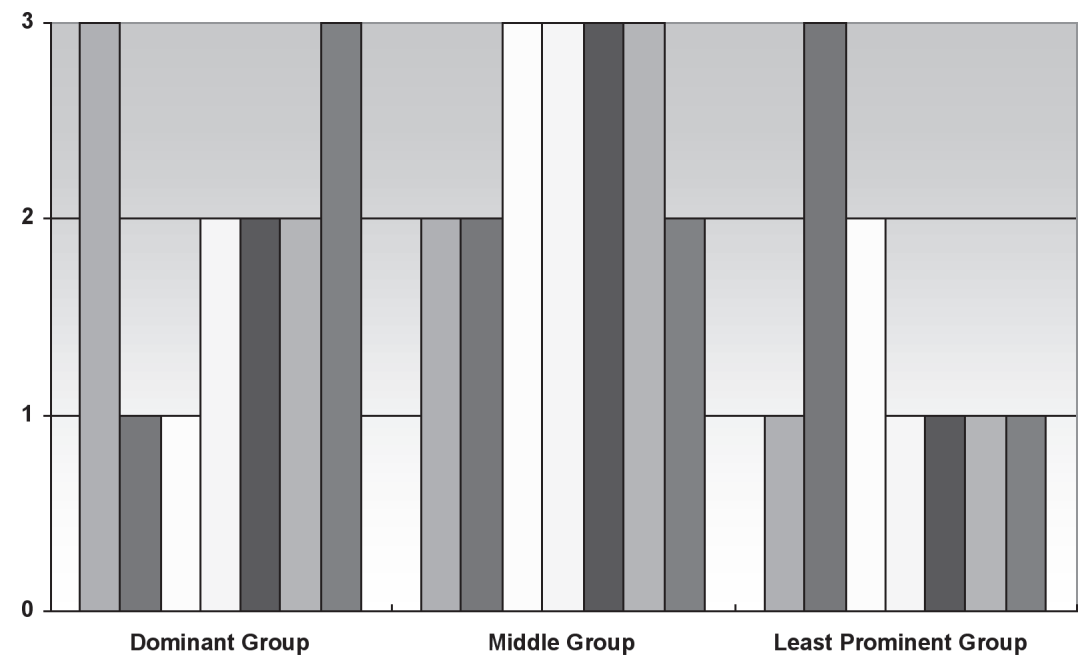

$\square$ NP $1 \square$ NP $2 \square$ NP $3 \square$ NP $4 \square$ NP $5 \square$ NP $6 \square$ NP 7 
Group 2 translations are dominant in three of the seven NPs analysed (4,5 and $6)$, comes second in other three phrases (1,2 and 7) and are less relevant in NP 3. Certainly, NPs 4, 5 and 6 cannot be translated into the TL without giving them careful thought. In fact, these are excellent examples of SL whose sense has to be weighed down before a TL instance is produced. It is, then, only natural that students make use of translation strategies to compensate their $\mathrm{L}_{2}$ deficit. Tables 12 and 13 confirm these findings. Students with English as mother tongue do considerably worse in these NPs. However, they do better in NP 1, where it is clear that students with Spanish as mother tongue fail to grasp the meaning of the phrase. For Nida and Taber (1982) this could be a case where a basic translation principle is violated, that is, the source text was misinterpreted by the translator.

One of the variables in our study was the individuals' L1. As part of our research, we set out to examine the frequencies and the percentages of all three groups of translations and all the strategies found in group 2 charted according to our students' mother tongue. Note that strategies 1-10 are only charted within Group 2 translations, that is, those where both a successful translation and strategy use were found.

TABLE 12

Students' L1 =Spanish. Percentage of translations categories (Groups 1, 2 and 3). Group 2 appears charted according to translation strategies used by Spanish-speaking students. Strategies references as in Table 3.

\begin{tabular}{|c|c|c|c|c|c|c|c|c|c|c|c|}
\hline \multirow[t]{2}{*}{ NP } & \multirow{2}{*}{$\begin{array}{c}\text { Group } \\
1 \%\end{array}$} & \multicolumn{9}{|c|}{ Group 2\% } & \multirow{2}{*}{$\begin{array}{c}\text { Group } \\
3 \%\end{array}$} \\
\hline & & ST 1 & ST 2 & ST 3 & ST 4 & ST 5 & ST 6 & ST 7 & ST 8 & ST 9 & \\
\hline 1 & 0.7 & & 12.1 & & & & 2.8 & 5 & & & 78.5 \\
\hline 2 & 77.1 & & 0.7 & & 8.5 & & 2.1 & & & 5 & 6.4 \\
\hline 3 & 92.8 & & 1.4 & & & & 1.4 & & & & 4.2 \\
\hline 4 & 22.1 & & & & & 20 & 9.2 & 15.7 & & & 32.8 \\
\hline 5 & 17.1 & & & & & 2.8 & & 1.4 & 50 & & 28.5 \\
\hline 6 & 5.7 & & & & & 1.4 & 10 & 6.4 & 39.2 & 2.1 & 35 \\
\hline 7 & 19.3 & & & & & 14.3 & 5.7 & & & 2.8 & 57.8 \\
\hline
\end{tabular}

TABLE 13

Students' L1 = English. Percentage of translations categories (Groups 1, 2 and 3). Group 2 appears charted according to translation strategies used by English-speaking students. Strategies references as in Table 3.

\begin{tabular}{|c|c|c|c|c|c|c|c|c|c|c|c|}
\hline \multirow{2}{*}{ NP } & Group & \multicolumn{9}{|l|}{ Group 2\% } & \multicolumn{9}{|l|}{} & \multirow{2}{*}{$\begin{array}{c}\text { Group } \\
3 \%\end{array}$} \\
\cline { 3 - 13 } & & ST 1 & ST 2 & ST 3 & ST 4 & ST 5 & ST 6 & ST 7 & ST 8 & ST 9 & \\
\hline 1 & 5.8 & 58.8 & & & & & 17 & & & & 17 \\
\hline 2 & 5.8 & & 29.4 & & & & 5.8 & 11.7 & & 5.8 & 41.2 \\
\hline 3 & 41.1 & & & & & & 5.8 & & & & 52.9 \\
\hline 4 & 11.7 & & & & & 5.8 & & & & & 83.3 \\
\hline 5 & & & & & & & & & 58.8 & & 41.2 \\
\hline 6 & 5.8 & & & & & & 5.8 & & 17.6 & & 70.6 \\
\hline 7 & & & & & & 11.8 & & & & & 88.2 \\
\hline
\end{tabular}


We should note here that the three individuals who do not fall under any of the two categories presented above have been discarded, as the data they contributed is not quantitatively important enough so as to approach a meaningful frequency analysis. As regards translation strategies, we found it necessary to run a new analysis on their frequency. However, this time, only information from Group 2 translations was computed, that is, only information obtained from translations proposed by students where the use of strategies was involved. In the following table (\# 14) the distribution of strategies is shown in detail. In the first column information pertaining to the whole sample is presented; in the second, information related to students whose L1 is Spanish is provided and, finally, in the third column the corresponding information for English-native students is found. In each subsample, data is charted according to the type of strategy used by the students (numbers as in Table 3), its relative frequency of occurrence and percentage. These were the results:

TABLE 14

\section{Frequency of translation strategies}

\begin{tabular}{|c|c|c|c|c|c|c|c|c|c|}
\hline \multirow{2}{*}{$\begin{array}{l}\text { NPs } \\
\text { NP } 1 \\
\end{array}$} & \multicolumn{3}{|c|}{ Whole sample } & \multicolumn{3}{|c|}{ L1 = Spanish } & \multicolumn{3}{|c|}{ L1 = English } \\
\hline & Strategy & Frequency & Percentage & Strategy & Frequency & Percentage & Strategy & Frequency & Percentage \\
\hline & 2 & 28 & 65.1 & 2 & 17 & 60.7 & 2 & 10 & 76.9 \\
\hline & 6 & 8 & 18.6 & 6 & 4 & 14.3 & 6 & 3 & 23.1 \\
\hline & 7 & 7 & 16.3 & 7 & 7 & 25 & & & \\
\hline \multirow[t]{6}{*}{ NP 2} & Strategy & Frequency & Percentage & Strategy & Frequency & Percentage & Strategy & Frequency & Percentage \\
\hline & 2 & 6 & 18.2 & 2 & 1 & 3.3 & 2 & 5 & 55.6 \\
\hline & 4 & 12 & 36.4 & 4 & 12 & 52.2 & 6 & 1 & 11.1 \\
\hline & 6 & 4 & 12.1 & 6 & 3 & 13 & 7 & 2 & 22.2 \\
\hline & 7 & 2 & 6.1 & 9 & 7 & 30.4 & 9 & 1 & 11.1 \\
\hline & 9 & 9 & 27.3 & & & & & & \\
\hline NPs & \multicolumn{3}{|c|}{ Whole sample } & \multicolumn{3}{|c|}{ L1 = Spanish } & \multicolumn{3}{|c|}{ L1= English } \\
\hline \multirow[t]{3}{*}{ NP 3} & Strategy & Frequency & Percentage & Strategy & Frequency & Percentage & Strategy & Frequency & Percentage \\
\hline & 2 & 2 & 28.6 & 2 & 2 & 33.3 & 6 & 1 & 100 \\
\hline & 6 & 5 & 71.5 & 6 & 4 & 66.7 & & & \\
\hline \multirow[t]{5}{*}{ NP 4} & Strategy & Frequency & Percentage & Strategy & Frequency & Percentage & Strategy & Frequency & Percentage \\
\hline & 4 & 1 & 1.5 & 5 & 28 & 44.4 & 5 & 1 & 100 \\
\hline & 5 & 29 & 43.9 & 6 & 13 & 20.6 & & & \\
\hline & 6 & 14 & 21.2 & 7 & 22 & 34.9 & & & \\
\hline & 7 & 22 & 33.3 & & & & & & \\
\hline NPs & \multicolumn{3}{|c|}{ Whole sample } & \multicolumn{3}{|c|}{$\mathbf{L 1}=$ Spanish } & \multicolumn{3}{|c|}{ L1 = English } \\
\hline \multirow[t]{4}{*}{ NP 5} & Strategy & Frequency & Percentage & Strategy & Frequency & Percentage & Strategy & Frequency & Percentage \\
\hline & 5 & 4 & 4.6 & 5 & 4 & 5.3 & 8 & 10 & 100 \\
\hline & 7 & 2 & 2.3 & 7 & 2 & 2.6 & & & \\
\hline & 8 & 81 & 93.1 & 8 & 70 & 92.1 & & & \\
\hline \multirow[t]{6}{*}{ NP 6} & Strategy & Frequency & Percentage & Strategy & Frequency & Percentage & Strategy & Frequency & Percentage \\
\hline & 5 & 2 & 2.2 & 5 & 2 & 2.4 & 8 & 3 & 60 \\
\hline & 6 & 16 & 18 & 6 & 14 & 16.9 & 6 & 2 & 40 \\
\hline & 7 & 9 & 10.1 & 7 & 9 & 10.8 & & & \\
\hline & 8 & 59 & 66.3 & 8 & 55 & 66.3 & & & \\
\hline & 9 & 3 & 3.4 & 9 & 3 & 3.6 & & & \\
\hline NPs & \multicolumn{3}{|c|}{ Whole sample } & \multicolumn{3}{|c|}{ L1 = Spanish } & \multicolumn{3}{|c|}{ L1 = English } \\
\hline \multirow[t]{4}{*}{ NP 7} & Strategy & Frequency & Percentage & Strategy & Frequency & Percentage & Strategy & Frequency & Percentage \\
\hline & 5 & 22 & 64.7 & 5 & 20 & 62.5 & 5 & 2 & 100 \\
\hline & 6 & 8 & 22.9 & 6 & 8 & 25.1 & & & \\
\hline & 9 & 4 & 11.8 & 9 & 4 & 12.5 & & & \\
\hline
\end{tabular}




\section{Analysis of the results}

As our study comprised both direct and indirect translation, we believe that the conclusions we advance in here should be understood in light of the interpretation difficulties posed by analysing students with different mother tongues. Based on frequency analysis, at least five considerations spring up.

First, students with English as L1 used a more limited range of translation strategies. This is not relevant in NPs 1, 2 and 7, where, as will be discussed later, direct translation actually was a problem for Spanish students. In NPs 3 and 4 only one of the English students in each case used a particular strategy, while in NPs 5 and 6 we find a situation where, comparatively, the strategies used by Spanish students outnumber those put into practice by their English peers.

Second, translation using a related word (strategy \#5), translation by paraphrase using unrelated words (strategy \#6) and translation by omission (strategy \#7) seem to be favoured by Spanish native speakers and more neglected by English students. This is particularly relevant in NPs 3, 4, 5 and 6. On the contrary, English native speakers do not show preferences for any of the translation strategies analysed here.

Third, it appears that strategy use is heavily NP-bound. Unacceptable translations abound in NPs 1 and 7, whereas exact translations are more frequent in NPs 2 and 3. Strategies are, thus, more widely used in NPs 4, 5 and 6. In this group of phrases, $50.4 \%$ of the solutions made use of some strategy, and 35,8\% resulted in failure, that is, an unacceptable translation was produced. These figures differ from the average for the whole NP sample:

FIGURE 3

Percentage of translation strategies use and unacceptable translations

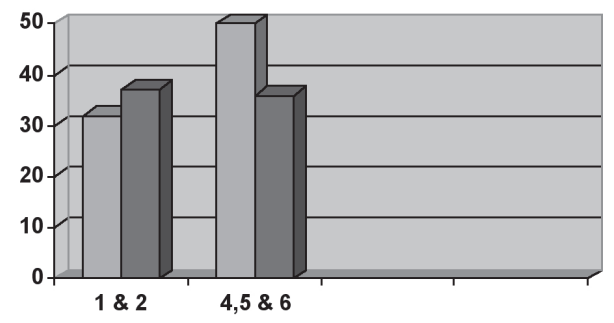

\begin{tabular}{|l|}
\hline$\square$ G2 Translations where \\
strategies are used \\
$\square$ G3 Unacceptable \\
translations \\
\hline
\end{tabular}

The following NP in the text:

- $\quad$ NP \# 4: NP's + NP (headword)

- $\quad{ }^{*} \mathrm{NP} \#$ 5: determiner $+\mathrm{CL}$ (adverb phrase + verbal phrase + NP $(\mathrm{NP}+\mathrm{NP})+\mathrm{NP}$ (headword))

- $\quad{ }^{*} \mathrm{NP} \#$ 6: AdjP +AdjP + NP (headword)

seem to induce students to use strategies to convey the same meaning into the target text.

When strategies are used successfully, unacceptability of students' translation decreases. In this group of NPs, unacceptable translations always come second after the strategy solution. This reinforces the idea that strategy-teaching has a definite pedagogical value.

NPs 1 and 7 rendered a high percentage of unacceptable translations. In the first, Spanish native speakers had difficulties in understanding the SL text, and clearly, 
features was misinterpreted. The apparent absence of verb interpreted by the students (as they took features as a noun) led to a failure in the translation of the nucleus of the NP, smash, making them attribute/ascribe/associate the modifiers of this NP to the nucleus of the following, Gwyneth Paltrow. This is the case of esta ingeniosa y sexy ganadora del Oscar Gwyneth Paltrow. In the second, the prepositional phrase acting as a premodifier misled Spanish students' grasping of the whole noun phrase. It seems obvious that this syntactic deviation played havoc with their expectations of what the role of prepositional phrases in noun phrases should be. It resulted in failed translations where the prepositional phrase was misplaced, or even suppressed, such as esta divertida obra vista detrás de las pantallas, or este divertido enfoque. In the case of English students, the prepositional phrase was the origin of many wrong translations, as they tried to place it before the nucleus of the NP, which is not possible in Spanish. Examples are esta divertida detrás-de-la-escena muestra, este detrás de normal mirada or este visto-tras-el-escenario de....

The translation of NP 2 resulted in a majority of adequate solutions. Surely enough, weak premodification and, especially, familiarity with the lexical items involved favoured the prominence of good translations. It is apparent that Spanish speakers, when using translation strategies, relied heavily on strategy 4 . When talking about this strategy, Mona Baker (1992) comments that the use of an explanation in this case is useful when the word is repeated several times in text, and once explained, the loan word can be used on its own. In this case, no explanation is added to the use of the loan word, as the students have in mind that everyone who reads the translation will know the meaning of this loan word. This is only natural since casting has become an outstanding Anglicism in Spanish. Models do castings and so on. Cast, as the nucleus of the NP, is very familiar, in terms of lexical meaning, to the Spanish students, as this word is usually used in colloquial conversation in its original, English form. Some of the solutions proposed by the Spanish students were un asombroso "cast," un divertido casting or un casting extraordinario. By way of contrast, English speakers produced $41.2 \%$ of unacceptable translations, such as mucha gente muy conocida, or un personaje increible. The different processes involved in direct and indirect translation might have fostered a distinctive use of strategies in both samples of students. Unfortunately, this study cannot report conclusive findings as there exists an imbalance between them: 140 / 17. Notwithstanding this, it must be stated that both samples present normal distributions in their respective theory test performance.

As a way of token, considering SICAL 1 linguistic appreciation scale, the evaluation parameters of translation work in opposite ways for speakers of different languages. Sense, wording and ST/ TT interrelations are affected by the direction of translation. Accordingly, it is necessary to recognize that translation strategies are biased by SL and translators' L1.

Fourth, strategy \#8 emerges strongly in both samples in NPs 5 and 6 . Even the percentages are comparable: $92.10 \%$ (Spanish speakers)/ 100\% (English speakers) for NP 5 and 66.3\% (Spanish speakers)/ 60\% (English speakers) for NP 6. This is the case of una película verdaderamente inolvidable or un verdadero ejemplo de película que uno no debería perderse (Spanish students/NP 5), tiene que ver esta película or debería ir a ver esta película (English students/NP 5), avalada por una crítica excelente or con una gran acogida por parte de la crítica (Spanish students/NP 6), y que tiene tan buena crítica or una destacada crítica (English students/NP 6). Grammatical category 
shifting apparently becomes more relevant when the lexical stock is similar in both languages, and this is the case with the two NPs under consideration. Probably this strategy was not even considered in Baker's taxonomy as its implementation cannot possibly result in success on every occasion. We could talk here about an "a posteriori" strategy rather than an "a priori” one. This also has pedagogical implications as to when translation strategies are to be introduced and taught. Students seem to fall back on this strategy as a natural move when other resources are scarce. As opposed to Gouadec (1989), we believe that, rather tentatively though, students' mistakes and translation strategies can be approached simultaneously as the strategy operates on an unconscious level. Palazuelos et al's distinction between performance and translation mistakes could similarly shed light on the nature of strategies such as number 8 . These authors stress the need for translators to be competent in reproduction skills, that is, the skills mostly associated with the translating process itself, rather than with L2 language performance background.

In the particular case of NP 4, the highest percentage corresponded to the exact translation. This could be due to the fact that best supporting actress-mejor actriz secundaria is nearly a fixed expression in both languages (at least in Spanish, in the film field, as far as we know), so students tend to use the expression they are accustomed to hear associated with pictures and films contexts.

Besides all this, Spanish students did not use strategies such as translation by a more general word and translation by cultural substitution. Their English classmates did not use the following strategies: translation using a loan word or a loan word plus an explanation, and translation by cultural substitution. In both cases, translation by cultural substitution was not used at all. This could be due to the fact that at this level of training in translation, students do not have the deep knowledge of the language they are learning, required to use this strategy. With a better command of the target language, students/translators will be able to use this tool to find translation equivalents where possible.

Moreover, students in general infer the instruction given, but attempt to propose new categories which emerge in a spontaneous way, increasing the range of possibilities and/or strategies used. This happens no matter the L1, so it can be associated with the stage of specialization in translation training. It should be stated, however, that this study has been concerned with two languages which, in terms of vocabulary stock and family origin, are very close. This implies that it is urgent to explore the territories in which Baker's translation strategies best deploy and manifest themselves if we are to grasp their ultimate impact on translation quality. We believe, based on evidence provided here, that the more divergent the languages implied, the more accurate Baker's translation strategies application will be. The reverse also applies.

\section{Conclusion}

This study suggests that our undergraduate students rely heavily on strategies when approaching the translation of units which present difficulties of a different nature. This is the case with both samples analysed here, Spanish and English speakers. The choice of these strategies depends on at least, two factors: translators' L1 and SL translation unit. Students' theoretical background seems to be related to the quality of translations as $86 \%$ of our sample got good to very good scores in the test which 
was devised to measure such knowledge. It should be remembered here that almost $67 \%$ of the translations produced were acceptable. One third of the solutions relied on translation strategies use, which, evidently, stresses the importance of translation teaching in universities and colleges. Lei (1999: 208) points out that "investigation into the current state of translation teaching" is necessary to resolve problems that teachers and students face in their day-to-day work. It is in this framework where this work can shed light on the boundaries between translation theory and practice: first, by providing trainers with feedback on students' performance and helping them design and shape teaching procedures that can be instrumental in implementing strategies use skills and, second, in a similar way, by confronting undergraduate students with the actual and potential range of translation strategies in light of work going on in their groups.

The pedagogical implications of our work back up the notion that it is essential that the teaching of translation be based on theoretical grounds as well as on classroom experiences that re-examine the implications of the first. This study corroborates the accuracy and pertinence of Baker's strategy taxonomy but also makes the point that students' use of such strategies varies to a certain degree. As Lei (1999:204) states:

"Some believe that anyone with a solid bilingual foundation could accomplish perfect translations and see no gap whatsoever. Translation ability, in this view, is something innate which cannot be acquired through study, which then begs the question: Is there any need to teach translation? In my opinion, the answer is yes, and my survey would indicate that nearly all translation teachers agree. We all believe that it is necessary to teach translation. As long as there is a distinct teaching objective, a feasible teaching programme, a set of practical textbooks and an experienced teacher, students will emerge better equipped to work in translation after they graduate [...] Then we must ask what problems need to be resolved in translation teaching. What should be taught and how it should be taught?"

\section{REFERENCES}

BAKER, M. (1992): In Other Words, London, Routledge.

Bassnett, S. (1991): Translation Studies, London, Routledge.

Catrord, J.C. (1965): A Linguistic Theory of Translation, London, O.U.P.

Gouadec, D. (1989): «Comprendre, évaluer, prévenir. Pratique, enseignement et recherche face à

l'erreur et à la faute en traduction», Traduction, Terminologie, Rédaction 2-2, pp. 35-54.

Greenbaum, S. and R. Quirk (1990): A Student's Grammar of the English Language, Harlow, Longman.

Hatim, B. and I. Mason (1990): Discourse and the Translator, Harlow, Longman.

Kussmaul, P. (1995): Training the Translator, Amsterdam, John Benjamins.

LeI, M. (1999): “Translation Teaching in China,” Meta 44-1, Les Presses de l'Université de Montréal.

Newmark, P. (1981): Approaches to Translation, Oxford, Pergamon Press.

Newmark, P. (1988): A Textbook of Translation, Hempstead, Prentice Hall.

NidA, E. (1964): Toward a Science of Translating with Special Reference to Principles and Procedures Involved in Bible Translating, Leiden, E.J. Brill.

NidA, E. and TABer, C. (1982): The Theory and Practice of Translation, Leiden, E.J. Brill.

Snell-Hornby, M. (1995): Translation Studies. An Integrated Approach, Amsterdam, John Benjamins.

Tytler, A.F. (1907): Essay on the Principles of Translation, London, Dent. 
Vinay, J.P. et J. Darbelnet (1977): Stylistique comparée du français et de l'anglais. Méthode de traduction, Montreal, Beauchemin.

Waddington, C. (2000): Estudio comparativo de diferentes métodos de evaluación de traducción general, Madrid, Universidad Pontificia Comillas.

\section{APPENDIX:}

SAMPLE QUESTIONS FROM THE THEORY TEST

\begin{tabular}{|c|c|}
\hline UNIT 1 & The translator, on a general level, faces two problems: \\
a) The meaning of the target text and finding an equivalent. \\
b) The meaning of the original text and the gist of the overall message. \\
c) The meaning of the original text and finding an equivalent in the target \\
language. \\
d) Producing a target version of the original text and finding an equivalent. \\
* Which of the following statements is not an aim of a translation theory: \\
a) To identify and define a translation problem. \\
b) To indicate all the factors that have to be taken into account in reading \\
the original text. \\
c) To list all the possible translation procedures. \\
d) To recommend the most suitable translation procedure, \\
UNIT 2 2 plus the appropriate translation. \\
The different linguistic choices made by the speaker depending on what kind \\
of action other than the immediate action of speaking they see themselves \\
as participating in are known as the \\
a) Field of discourse \\
b) Tenor of discourse \\
c) Mode of discourse \\
d) Linguistic discourse \\
The use of -ing forms in English, compared with Spanish, shows the following \\
problem of non-equivalence: \\
a) Differences in form \\
b) Differences in meaning \\
c) Differences in frequency and purpose of using specific words \\
d) Differences in expressive meaning \\
c) Less flexible in patterning and less transparent in meaning than idioms \\
d) Less flexible in patterning and more transparent in meaning than idioms \\
(the set of collocates which are typically associated with a word is known as \\
a) Register \\
b) Range \\
c) Reference \\
d) Level of specificity \\
Collocations are: \\
a) More flexible in patterning and less transparent in meaning than idioms \\
b) More flexible in patterning and more transparent in meaning than \\
UNIT 3
\end{tabular}




\begin{tabular}{|c|l|}
\hline UNIT 4 & * The surface connections which establish interrelationships between persons \\
and events, allowing us to trace participants in a text and to interpret the way \\
in which different parts of the text relate to each other are known as \\
a) Coherence \\
b) Implicature \\
c) Cohesion \\
d) Lexical patterning \\
* The semantic connections which allow us to make sense of a text as a unit of \\
meaning are known as \\
a) Cohesion \\
b) Coherence and implicature \\
c) Lexical patterning \\
d) Meaning \\
* Reiteration and collocation are two categories of \\
a) Reference \\
b) Substitution \\
c) Lexical cohesion \\
d) Conjunction \\
* In 'Last month, I bought a nice computer, but the following week, \\
there was a cheaper one at the same store,' the use of 'one' is an instance of \\
a) Substitution \\
b) Ellipsis \\
c) Cataphoric \\
d) Reference
\end{tabular}

